3. В. Валіулліна

Національний університет водного господарства та природокористування, м. Рівне, Украӥна

\title{
ІНФОРМАЦЙНА БЕЗПЕКА КОРПОРАТИВНОЇ ЕКОНОМІКИ В УМОВАХ ГЛОБАЛІЗАЦІЙНИХ ПРОЦЕСІВ
}

У сучасних умовах XXI ст. інформаційна безпека корпоративної економіки набувас все вагомішої ролі, а питання їі забезпечення стають дедалі гострішими. Стрімке впровадження інформаційних технологій у всі сфери життедіяльності суспільства та розвиток корпоративної економіки в умовах глобалізаційних процесів актуалізує проблему визначення обгрунтованих та ефективних шляхів забезпечення інформаційної безпеки.

Метою написання даної статті є теоретико-методологічний аналіз і виявлення основних складників забезпечення інформаційної безпеки корпоративної економіки в умовах глобалізації для захисту інформації, напрямів підвищення ефективності та конкурентоспроможності економіки на світовому ринку. У процесі дослідження було застосовано такі методи: системний $\mathbf{i}$ порівняльний аналіз, метод узагальнення.

Розглянуто теоретико-методологічні основи інформаційної безпеки корпоративної економіки. Систематизовано i надано результати порівняльного аналізу категорії «інформаційна безпека». Інформаційну безпеку запропоновано розглядати як інтегрований складник процесу забезпечення захисту інформації від внутрішніх і зовнішніх загроз і створення сприятливих умов для ефективного функціонування корпорацій i підвищення їх конкурентоспроможності.

Досліджено особливості формування ефективної системи забезпечення інформаційної безпеки. Запропоновано вирішення проблеми ефективного функціонування системи інформаційної безпеки корпоративної економіки в умовах глобалізаційних процесів шляхом упровадження комплексу заходів, які враховують основні компоненти інформаційної безпеки: законодавчу; економічну; програмно-технічну; адміністративно-управлінську.

Наукова новизна дослідження полягає в удосконаленні науково-методичного підходу до визначення складників інформаційної безпеки корпоративної економіки, які забезпечують комплекс політичних, економічних, організаційних, технічних та інших заходів, що сприяють реалізації інформаційних прав і інтересів корпорацій.

Практичне значення одержаних результатів - забезпечення захисту інформації корпорацій від внутрішніх і зовнішніх загроз, створення сприятливих умов для ефективного функціонування корпорацій і підвищення їх конкурентоспроможності.

Розробка заходів щодо забезпечення взаємодії інституційного середовища - подальша перспективна тема досліджень розвитку корпоративної економіки на основі паритету інформаційної безпеки.

Ключові слова: інформація; інформаційна безпека; загрози; корпорація; глобалізація.

\section{3. В. Валиуллина}

Национальный университет водного хозяйства и природопользования,

$$
\text { 2. Ровно, Украина }
$$

\section{ИНФОРМАЦИОННАЯ БЕЗОПАСНОСТЬ КОРПОРАТИВНОЙ ЭКОНОМИКИ В УСЛОВИЯХ ГЛОБАЛИЗАЦИОННЫХ ПРОЦЕССОВ}

В современных условиях XXI в. информационная безопасность корпоративной экономики приобретает все более весомую роль, а вопрос её обеспечения становится все острее. Стремительное внедрение информационных технологий во все сферы жизнедеятельности общества и развитие корпоративной экономики в условиях глобализационных процессов актуализирует проблему определения обоснованных и эффективных путей обеспечения информационной безопасности.

(C) Валіулліна 3. В., 2016 
Целью написания данной статьи является теоретико-методологический анализ и выявление основных составляющих обеспечения информационной безопасности корпоративной экономики в условиях глобализации для защиты информации, направлений повышения эффективности и конкурентоспособности экономики на мировом рынке. В процессе исследования были применены следующие методы: системный и сравнительный анализ, метод обобщения.

Рассмотрены теоретико-методологические основы информационной безопасности корпоративной экономики. Систематизированы и предоставлены результаты сравнительного анализа категории «информационная безопасность». Информационную безопасность предложено рассматривать как интегрированную составляющую процесса обеспечения защиты информации от внутренних и внешних угроз и создание благоприятных условий для эффективного функционирования корпораций и повышение их конкурентоспособности.

Исследованы особенности формирования эффективной системы обеспечения информационной безопасности. Предложено решение проблемы эффективного функционирования системы информационной безопасности корпоративной экономики в условиях глобализационных процессов путём внедрения комплекса мероприятий, учитывающих основные компоненты информационной безопасности: законодательную; экономическую; программно-техническую; административно-управленческую.

Научная новизна исследования заключается в совершенствовании научнометодического подхода к определению составляющих информационной безопасности корпоративной экономики, который обеспечивается целым комплексом политических, экономических, организационных, технических и других мероприятий, способствующих реализации информационных прав и интересов корпораций.

Практическое значение полученных результатов - обеспечение защиты информации корпораций от внутренних и внешних угроз, создания благоприятных условий для эффективного функционирования корпораций и повышение их конкурентоспособности.

Разработка мероприятий по обеспечению взаимодействия институциональной среды дальнейшая перспективная тема исследований развития корпоративной экономики на основе паритета информационной безопасности.

Ключевые слова: информация; информационная безопасность; угрозы; корпорация; глобализация.

\author{
Z. V. Valiullina \\ National University of Water Management and Nature Resources Use, \\ Rivne, Ukraine
}

\title{
INFORMATION SECURITY OF CORPORATE ECONOMICS IN THE CONDITIONS OF GLOBALIZATION
}

In modern conditions of the $21^{\text {st }}$ century, information security of corporate economics is gaining more importance while the task of its provision becomes more and more acute. Rapid introduction of information technologies into all spheres of vital activities of the society and the development of corporate economy under conditions of globalization processes call for the definition of substantiated and efficient ways of ensuring information security.

The purpose of writing this article is theoretical-methodological analysis and identification of the basic components of provision of information security of the corporate economy under conditions of globalization to protect information, directions of improving the efficiency and competitiveness of the economy on the world market. In the course of the study we applied the following methods: systematic and comparative analysis, the method of generalization.

The paper considers theoretical-methodological fundamentals of information security of the corporate economy. The results of the comparative analysis of the category of "information security" were systemized and are given here. Information security is proposed to be regarded as an integrated component of the process of ensuring the protection of information from internal and external threats and creating favorable conditions for the efficient functioning of corporations and enhancing their competitiveness. 
Peculiarities of setting up an efficient system of information security were researched. A solution to the problem of efficient functioning of the system of information security of corporate economics in the conditions of globalization was proposed by adopting a set of measures that take into account the main components of information security: legislative; economic; program-technical; administrative management.

The scientific novelty of the research lies in the improvement of scientific and methodical approach to identifying components of information security of the corporate economy, which provide a range of political, economic, organizational, technical and other measures that contribute to the realization of informational rights and interests of corporations.

The practical significance of obtained results is to provide protection of the information of corporations from internal and external threats, creating favorable conditions for the efficient functioning of corporations and enhancing their competitiveness.

The design of measures to ensure the interaction between institutional environment is a promising topic of the further research into the corporate economy based on parity of information security.

Keywords: information, information security, threats, corporation, globalization.

Вступ. У сучасних умовах XXI ст. інформаційна безпека корпоративної економіки набуває все вагомішої ролі, а питання іiі забезпечення стають дедалі гострішими. Стрімке впровадження інформаційних технологій у всі сфери життєдіяльності суспільства та розвиток корпоративної економіки в умовах глобалізаційних процесів актуалізує проблему визначення обгрунтованих та ефективних шляхів забезпечення інформаційної безпеки.

Формування корпоративної економіки в умовах глобалізаційних процесів порушує широке коло проблемних питань, одним із яких $\epsilon$ підвищення інформаційної безпеки.

В умовах глобалізаційних процесів корпоративну економіку, на наш погляд, слід розглядати як динаміку злиттів і поглинань, що являє собою трансформаційну стратегію економіки, спрямовану на підвищення iii ефективності та конкурентоспроможності на світовому ринку.

Країни, які не можуть забезпечити власну інформаційну безпеку, стають неконкурентоспроможними i, як наслідок, не можуть брати участь у боротьбі за розподіл ринків і ресурсів. Можна стверджувати, що розпад великих держав відбувся не в останню чергу через неспроможність ефективного управління на власній території та невідповідність інформаційної структури новим умовам існування. Отже, незаперечним є те, що в будь-якій розвиненій країні має функціонувати система забезпечення інформаційної безпеки, а функції та повноваження відповідних державних органів повинні бути закріплені законодавчо [11, с.90].

Таким чином, у зв'язку зі зростанням динаміки злиттів і поглинань компаній як складової частини трансформаційної стратегії економіки України, спрямованої на підвищення іiі ефективності та конкурентоспроможності на світовому ринку, проблема інформаційної безпеки потребує постійної і прискіпливої уваги.

Науковий доробок осмислення проблем реалізації інформаційної безпеки в сучасному постіндустріальному суспільстві формували праці таких ученихекономістів: О. А. Сороківська [1], Л. Дж. Хоффман [2], В. Богуш [3], О. М. Горбатюк [4; 5], Б. А. Кормич [6], О. І. Крюков [7], М. Гуцалюк [9], О. М. Степко [11], І. Л. Сазонець [13] та ін. Проте на сьогодні питання, пов’язані із функціонуванням та захистом інформації, у корпоративній економіці залишаються відкритими і потребують подальших досліджень. 
Постановка завдання. Метою написання даної статті $\epsilon$ теоретикометодологічний аналіз i виявлення основних складників забезпечення інформаційної безпеки корпоративної економіки в умовах глобалізації для захисту інформації, підвищення ефективності та конкурентоспроможності економіки на світовому ринку. Теоретичною $\mathrm{i}$ методологічною основою дослідження $\epsilon$ монографії та науково-аналітичні статті українських i зарубіжних учених, законодавчі й нормативно-правові акти Верховної Ради України і Кабінету Міністрів України, загальнодержавні програми України, що регулюють діяльність забезпечення національної безпеки країни, результати власних досліджень автора. У процесі дослідження застосовано методи: системного і порівняльного аналізу, метод узагальнення.

Результати. В умовах глобалізаційних процесів поглибленого аналізу потребує сучасний стан інформаційної безпеки корпоративного сектора України, також необхідне виявлення ключових деструктивних чинників, що гальмують його розвиток.

Поширення тенденцій інтегрованості національних економік у світове господарство впродовж двох останніх століть відбувається насамперед за рахунок розвитку корпоративних відносин. Отже, стрімкий розвиток корпоративної форми сприяє перетворенню корпоративних структур на домінуючий чинник розвитку світової економіки. Світові тенденції підтверджують, що таким структурам належить провідна роль не лише в інноваційному розвитку, а й в економічному зростанні загалом. Саме завдяки здатності корпорацій акумулювати значні матеріальні, людські та фінансові ресурси для виконання науково-технічних i виробничо-господарських завдань відбувається стрімкий розвиток інноваційних технологій i їх масштабне поєднання з виробничими потужностями індустріального суспільства у XX ст. Корпоративні форми підвищують рівень макроекономічного регулювання виробництва, стабільність економічного співробітництва (у тому числі й міжнародного), є партнерами держави під час розробки та реалізації стратегічної лінії в процесі модернізації економіки. Таким чином, тенденції їх «функціонування визначають закономірності розвитку світового господарства i носять універсальний характер. Зокрема, до таких закономірностей слід віднести концентрацію капіталу, інтеграцію промислового i фінансового капіталу, диверсифікацію форм i напрямів діяльності, глобалізацію та інтернаціоналізацію» [10, с. 7].

Динамічний розвиток економічних, політичних, соціальних подій XXI ст. дозволив сформулювали нове уявлення про інформацію як один із факторів (ресурсів) виробництва. На макрорівні інформація впевнено займає позиції головного фактора могутності держави, адже наявність у державі найсучасніших інформаційних технологій дозволяє ій ефективно управляти інформацією та у подальшому нарощувати свою економічну міцність [9, с. 2].

На мікрорівні обсяг, достовірність, цілісність, якість обробки інформації визначають ефективність дій менеджменту підприємства, а отже, актуалізують застосування інформаційних технологій в управлінні грошово-кредитними, фінансовими, соціально-економічними процесами даного підприємства. «Без необхідного обсягу та якості інформації неможливо забезпечити розвиток суб'єкта господарювання на основі високотехнологічного виробництва, ефективних методів організації праці» [1, с. 34]. 
У ході дослідження наукових підходів до дефініції «інформаційна безпека» було проведено порівняльний аналіз даної категорії, результати якого систематизовано та подано нижче (таблиця).

Підходи до визначення дефініції «інформаційна безпека»*

Таблиця

\begin{tabular}{|c|c|}
\hline Автори & Визначення \\
\hline $\begin{array}{l}\text { О.А. Сороківська, } \\
\text { В.Л. Гевко }\end{array}$ & $\begin{array}{l}\text { Суспільні відносини щодо створення і підтримання на належному рівні } \\
\text { життєдіяльності інформаційної системи суб'єкта господарської діяльності }\end{array}$ \\
\hline Л.Дж. Хоффман & $\begin{array}{l}\text { Стан інформації, за якого забезпечується збереження } \\
\text { політикою безпеки властивостей інформації }\end{array}$ \\
\hline $\begin{array}{l}\text { В. Богуш, } \\
\text { О. Юдін }\end{array}$ & $\begin{array}{l}\text { Стан захищеності інформаційного середовища суспільства, який } \\
\text { забезпечує його формування, використання i розвиток в інтересах } \\
\text { громадян, організацій, держави }\end{array}$ \\
\hline О.М. Горбатюк & $\begin{array}{l}\text { Стан захищеності потреб в інформації особистості, суспільства і держави, } \\
\text { за якого забезпечується їх існування і прогресивний розвиток незалежно } \\
\text { від наявності внутрішніх і зовнішніх інформаційних загроз }\end{array}$ \\
\hline О. Литвиненко & $\begin{array}{llccccc}\text { Один із аспектів розгляду } & \text { інформаційних } & \text { відносин } & \text { у } & \text { межах } \\
\text { інформаційного законодавства } & & & \end{array}$ \\
\hline Б.А. Кормич & $\begin{array}{l}\text { Захищеність установлених законом правил, за якими відбуваються } \\
\text { інформаційні процеси в державі, що забезпечують гарантовані } \\
\text { Конституцією умови існування і розвитку людини, усього суспільства та } \\
\text { держави }\end{array}$ \\
\hline O.I. Крюков & $\begin{array}{l}\text { Суспільні правовідносини щодо процесу організації створення, } \\
\text { підтримки, охорони та захисту необхідних для особи (людини чи } \\
\text { юридичної особи, установи, підприємства, організації), суспільства і } \\
\text { держави безпечних умов їх життєдіяльності; суспільні правовідносини } \\
\text { пов’язані з організацією технологій створення, поширення, зберігання та } \\
\text { використанням інформації (відомостей, даних, знань) для забезпечення } \\
\text { функціонування і розвитку інформаційних ресурсів людини, суспільства, } \\
\text { держави }\end{array}$ \\
\hline $\begin{array}{l}\text { Закон України } \\
\text { «Про основні } \\
\text { засади розвитку } \\
\text { інформаційного } \\
\text { суспільства в } \\
\text { Україні } \\
\text { на 2007-2015 рр.» }\end{array}$ & $\begin{array}{l}\text { Стан захищеності життєво важливих інтересів людини, суспільства і } \\
\text { держави, за якого запобігають нанесення шкоди через: неповноту, } \\
\text { невчасність і недостовірність використовуваної інформації; негативний } \\
\text { інформаційний вплив; негативні наслідки застосування інформаційних } \\
\text { технологій; несанкціоноване поширення, використання, порушення } \\
\text { цілісності, конфіденційності та доступності інформації }\end{array}$ \\
\hline
\end{tabular}

Відповідно до вищезазначеного матеріалу інформаційну безпеку розглядають за трьома основними характеристиками: стан захищеності інформаційного середовища, суспільні відносини та захищеність установлених законом правил.

Узагальнюючи підходи до розуміння сутності інформаційної безпеки, слід наголосити, що в умовах глобалізаційних процесів інформаційну безпеку корпоративної економіки запропоновано визначати як інтегрований складник процесу забезпечення захисту інформації від внутрішніх i зовнішніх загроз i створення сприятливих умов для ефективного функціонування корпорацій i підвищення їх конкурентоспроможності.

Головним «гравцем» ринку в недержавному секторі економіки і стрижнем будь-якої економічної системи, побудованої не на державно-монополістичних, а на конкурентних засадах, є корпорації. Проте необхідно зазначити, що повсякденна практика функціонування недержавних об'єктів свідчить про їх підвищену порівняно 3 державними структурами уразливість до протиправних та інших посягань із боку різного роду кримінальних структур, а також окремих осіб. 
Необхідність забезпечення безпеки активів корпорації зобов'язує їх займатися діяльністю, яка раніше була виключно прерогативою спеціальних державних органів. Забезпечення безпеки приватної діяльності стає важливою необхідністю, $є$ основою функціонування недержавних об'єктів. Отже, охорона корпорацій i забезпечення інформаційної безпеки корпоративної діяльності - стрижнева проблема, що передбачає вживання низки організаційно-правових, технікотехнологічних, інформаційних, адміністративних, виховних, фінансових i спеціальних заходів, спрямованих на виявлення, попередження і припинення загрози стабільності функціонування і розвитку корпорацій. Цей процес передбачає забезпечення безпеки інформації, охорону приватної власності корпорацій i фізичний захист іiі персоналу. При цьому до власності відносять, по-перше, основне матеріальне майно: приміщення, земельну ділянку, парк техніки, сировину й інвентар, а також допоміжне устаткування, призначене для збереження, переробки і перевезення вантажів. По-друге, сюди ж варто віднести інтелектуальну власність, що містить інформацію, яка $є$ актив компанії про власність власника, а також знання і досвід співробітників корпорацій, їх професійні секрети і винаходи. Корпорації, які прагнуть мати власну службу безпеки, не повинні розглядати витрати на iї створення як необгрунтовано високі, оскільки життя та репутація цінуються набагато вище. Проблемою корпорацій $є$ те, що отримання ними надприбутків не сприяє усвідомленню того факту, що багатство неминуче переводить їх у «групу ризику». Як показує сумний досвід, вітчизняні корпорації починають вживати суттєві заходи із забезпечення власної безпеки, безпеки інформації лише після виникнення проблем [12, с. 61].

Виділимо важливі проблеми інформаційної безпеки корпоративної економіки. По-перше, до них слід віднести забезпечення захисту і контролю за інформаційним простором від несанкціонованого доступу до інформації, по-друге, удосконалення нормативно-правового поля інформаційної сфери; по-третє, залучення інвестицій для скорочення технічного відставання інформаційних технологій; по-четверте, використання новітнього програмного забезпечення та техніки.

Проведене дослідження засвідчило, що ефективне функціонування інформаційної безпеки корпоративної економіки в умовах глобалізаційних процесів необхідно розглядати як сукупність державної та недержавної системи захисту (рисунок). Основні іiі компоненти: законодавча, економічна, програмно-технічна, адміністративно-управлінська.

Складниками єдиної системи забезпечення інформаційної безпеки корпорацій $\epsilon[14$, с. 97]:

- державна система, представлена правоохоронними органами та спецслужбами (наприклад, Служба безпеки України, Рада національної безпеки і оборони України);

- недержавна система, представлена приватними охоронними, охороннотехнічними підприємствами, комерційними службами безпеки, підприємствами різної форми власності, інформаційними бюро, службами безпеки банків, профільними факультетами, кафедрами вищих навчальних закладів. 


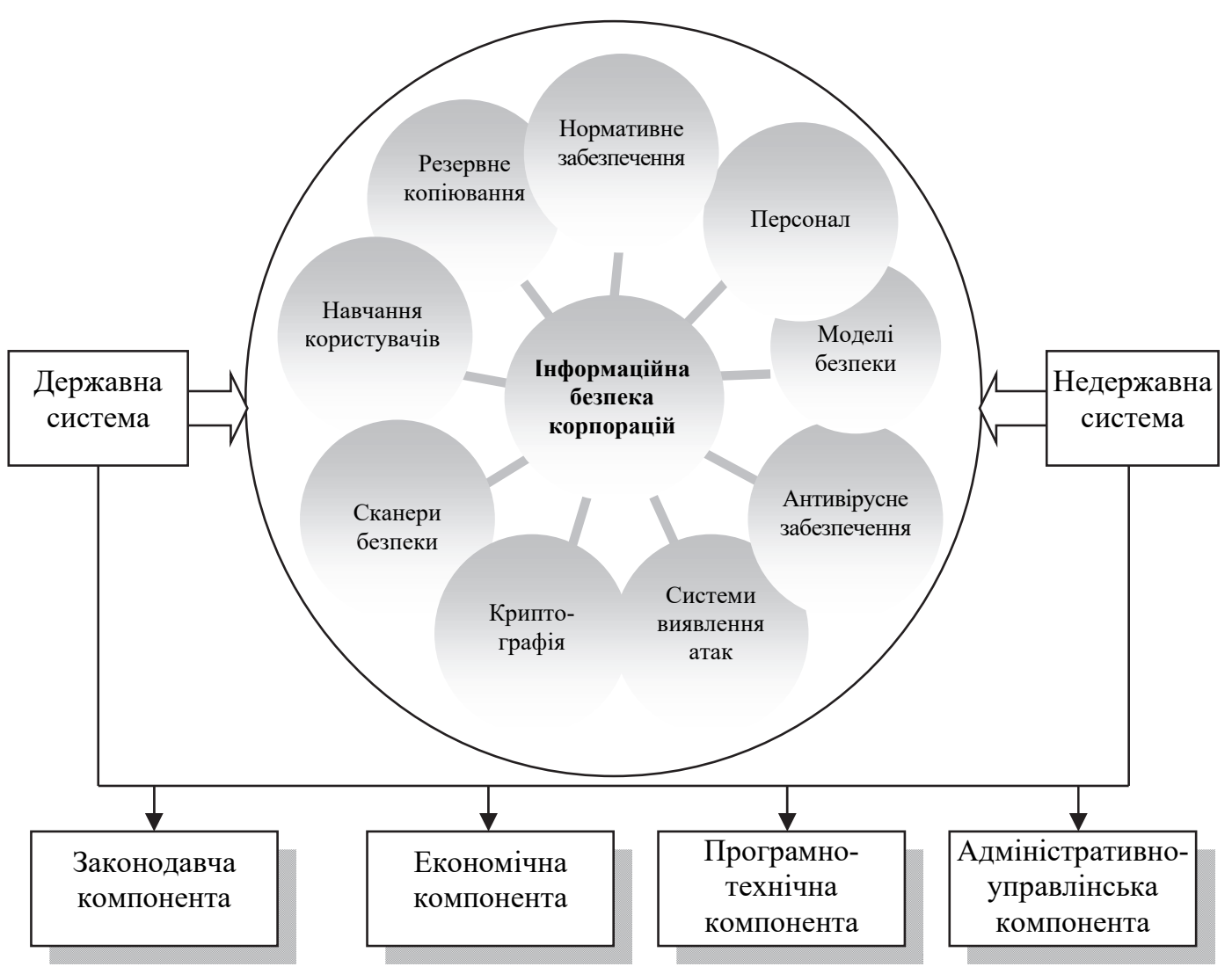

Рисунок. Структура системи інформаційної безпеки корпоративної економіки

До законодавчої компоненти слід віднести: розробку єдиної комплексної системоутворювальної нормативно-правової бази, яка регулювала б функціонування та сприяла стимулюванню розвитку інформаційної безпеки корпоративної економіки.

Адміністративно-управлінська компонента в першу чергу повинна відповідати за:

- створення органів на державному рівні та на рівні корпорації, що координують розвиток системи інформаційної безпеки;

- підвищення уваги керівництва до управління персоналом і фізичним захистом інформації;

- розробку та забезпечення концепції і програми розвитку інформаційної безпеки на всіх рівнях; безпеки;

- активізацію міжнародного співробітництва у сфері інформаційної

- гармонізацію навчання персоналу із відповідними світовими нормами й стандартами. 
Значну увагу потрібно приділити економічній компоненті, яка в сучасних умовах глобалізації повинна:

- створювати умови для стабільного економічного зростання та підвищення конкурентоспроможності корпоративної економіки;

- забезпечувати пошук і виділення необхідних ресурсів для посилення інформаційної безпеки;

- створювати сприятливе інвестиційне середовище для залучення інвестицій.

Для захисту та посилення інформаційної безпеки, на наш погляд, головною є програмно-технічна компонента, що відповідає за:

- розвиток вітчизняної індустрії інформації відповідно до сучасної геополітичної ситуації у світі;

- розробку програмних та апаратних засобів криптографічного захисту інформації, які б захищали інформаційні ресурси від несанкціонованого доступу для забезпечення конфіденційності;

- ліцензування та розробку критеріїв сертифікації технологій;

- інформатизацію та автоматизацію виробничих процесів і робочих місць співробітників.

Необхідний рівень інформаційної безпеки забезпечує сукупність політичних, економічних, організаційних заходів, спрямованих на попередження, виявлення i нейтралізацію тих обставин, факторів і дій, які можуть завдати збитку або перешкодити реалізації інформаційних прав, потреб та інтересів країни i iï громадян.

Вищесказане дозволяє зробити висновок, що необхідний рівень інформаційної безпеки корпоративної економіки забезпечують за допомогою цілого комплексу політичних, економічних, організаційних та інших заходів, які допомагають реалізації інформаційних прав та інтересів корпорацій

Висновки. Підсумовуючи, наголосимо, що сучасна геополітика визначає інформаційну безпеку як один із головних напрямів соціально-економічного розвитку держави. Необхідним для забезпечення інформаційної безпеки корпоративної економіки $є$ застосування на практиці комплексну заходів, що поєднує такі засоби впливу, як законодавчий, економічний; програмно-технічний; адміністративно-управлінський. Найскладнішими для реалізації є удосконалення нормативно-правової бази, пошук і виділення необхідних ресурсів для розвитку інформаційної безпеки, а також навчання персоналу відповідним світовим нормам і стандартам, кооперація фахівців із різних галузей.

Розробка заходів із забезпечення взаємодії інституційного середовища подальша перспективна тема досліджень розвитку корпоративної економіки на основі паритету інформаційної безпеки.

Наукова новизна дослідження полягає в удосконаленні науково-методичного підходу до визначення складників інформаційної безпеки корпоративної економіки, які забезпечують комплекс політичних, економічних, організаційних, технічних та інших заходів, що допомагають реалізації інформаційних прав i iнтересів корпорацій.

Практичне значення одержаних результатів - забезпечення захисту інформації корпорацій від внутрішніх і зовнішніх загроз, створення сприятливих умов для ефективного функціонування корпорацій i підвищення їх конкурентоспроможності. 


\section{Бібліографічні посилання}

1. Сороківська, О. А. Інформаційна безпека підприємства: нові загрози та перспективи [Текст] / О. А. Сороківська, В. Л. Гевко // Вісн. Хмельниц. нац. ун-ту. Сер.: Екон. науки. - 2010. - № 2. - Т. 2. - С. 32-35.

2. Хоффман, Л.Дж. Современные методы защиты информации [Текст] / Л. Дж. Хоффман; пер. с англ. - М.: Сов. радио, 1980. - 57 с.

3. Богуш, В. Інформаційна безпека держави [Текст] / В. Богуш, О. Юдін; [гол. ред. Ю.О. Шпак]. - К.: МК-Прес, 2005. - 432 с.

4. Горбатюк, О. М. Сучасний стан та проблеми інформаційної безпеки України на рубежі століть [Текст] / О. М. Горбатюк // Вісн. Київ. ун-ту ім. Т. Шевченка. Сер.: Міжнар. відносини. - 1999. - Вип. 14. - С. 46-48.

5. Литвиненко, О. Інформація і безпека [Текст] / О. Литвиненко // Нова політика. - 1998. - № 1. - С. 47-49.

6. Кормич, Б. А. Інформаційна безпека: організаційно-правові основи [Текст]: навч. посіб. / Б. А. Кормич. - К.: Кондор, 2008. - 384 с.

7. Крюков, О. І. Інформаційна безпека держави в умовах глобалізації [Електронний ресурс] / О. І. Крюков // Державне будівництво. - 2007. - № 2. Режим доступу: http://www.nbuv.gov.ua/e-journals/DeBu/2007-2/doc/1/10.pdf. Заголовок з екрана.

8. Закон України «Про основні засади розвитку інформаційного суспільства в Україні на 2007-2015 рр.» від 09.01.2007 p. № 537-V [Електронний ресурс]. Режим доступу: http://zakon3.rada.gov.ua/laws/show/537-16. - Заголовок з екрана.

9. Гуцалюк, М. Інформаційна безпека України: нові загрози [Текст] / М. Гуцалюк // Бизнес и безопасность. - 2003. - № 5. - С. 2-3.

10.Федулова, Л. І. Корпоративні структури в національній інноваційній системі України [Текст]: монографія / Л. І. Федулова, В. Л. Осецький, Ю. В. Гончаров, О Ю. Рудченко, Ю. М. Бажал; Ін-т економіки та прогнозування НАН України. - К. : Вид-во УкрIНТЕІ, 2007. -812 с.

11.Степко, О. М. Аналіз головних складових інформаційної безпеки держави [Текст] О. М. Степко // Наук. вісн. Ін-ту міжнар. відносин НАУ. - Сер. : Економіка, право, політологія, туризм. - К., 2011. - Вип. 1 (3). - С. 90-99.

12.Назаров, В. В. Деякі аспекти забезпечення безпеки підприємницької діяльності [Текст] / В. В. Назаров // Матеріали Всеукр. науково-практ. конф.: [«Недержавна система безпеки підприємництва як складова національної безпеки України»]. - К., 2013. - С. 60-61.

13.Сазонець, І. Л. Міжнародні стандарти безпеки підприємств [Текст]: навч. посіб./ І. Л. Сазонець. - Рівне: Волин. обереги, 2015. - 352 с.

14.Нашинець-Наумова А. Ю. Правове регулювання інформаційної безпеки корпорацій [Текст] / А. Ю. Нашинець-Наумова // Правова інформатика. - 2014. № 4 (44). - C. 95-99. 


\section{Bibliographic references}

1. Sorokivska, O. A. Informatsiina bezpeka pidpryiemstva: novi zahrozy ta perspektyvy / O. A. Sorokivska, V. L. Hevko // Visn. Khmelnyts. nats. un-tu. Ser.: Ekon. nauky. - 2010. - № 2. - T. 2. S. 32-35.

2. Khoffman, L.Dzh. Sovremennye metody zashchyty ynformatsyy / L. Dzh. Khoffman; per. s anhl. M.: Sov. radyo, 1980. $-57 \mathrm{~s}$.

3. Bohush, V. Informatsiina bezpeka derzhavy / V. Bohush, O. Yudin; [hol. red. Iu.O. Shpak]. - K.: MK-Pres, 2005. - $432 \mathrm{~s}$.

4. Horbatiuk, O. M. Suchasnyi stan ta problemy informatsiinoi bezpeky Ukrainy na rubezhi stolit / O. M. Horbatiuk // Visn. Kyiv. un-tu im. T. Shevchenka. Ser.: Mizhnar. vidnosyny. - 1999. - Vyp. 14. C. 46-48. C. 47-49.

5. Lytvynenko, O. Informatsiia i bezpeka / O. Lytvynenko // Nova polityka. - 1998. - № 1. -

6. Kormych, B. A. Informatsiina bezpeka: orhanizatsiino-pravovi osnovy: navch. posib. / B. A. Kormych. - K.: Kondor, 2008. - 384 s.

7. Kriukov, O. I. Informatsiina bezpeka derzhavy v umovakh hlobalizatsii [Electronic resource] / O. I. Kriukov // Derzhavne budivnytstvo. - 2007. - № 2. - Access mode: http://www.nbuv.gov.ua/ejournals/DeBu/2007-2/doc/1/10.pdf.

8. Zakon Ukrainy «Pro osnovni zasady rozvytku informatsiinoho suspilstva v Ukraini na 2007-2015 rr» vid 09.01.2007 r. № 537-V [Electronic resource]. - Access mode: http://zakon3.rada.gov.ua/laws/show/537-16.

9. Hutsaliuk, M. Informatsiina bezpeka Ukrainy: novi zahrozy / M. Hutsaliuk // Byznes y bezopasnost. - 2003. - № 5. - C. 2-3.

10. Fedulova, L. I. Korporatyvni struktury v natsionalnii innovatsiinii systemi Ukrainy: monohrafiia / L. I. Fedulova, V. L. Osetskyi, Iu. V. Honcharov, O Iu. Rudchenko, Iu. M. Bazhal; In-t ekonomiky ta prohnozuvannia NAN Ukrainy. - K. : Vyd-vo UkrINTEI, 2007. -812 s.

11. Stepko, O. M. Analiz holovnykh skladovykh informatsiinoi bezpeky derzhavy O. M. Stepko // Nauk. visn. In-tu mizhnar. vidnosyn NAU. - Ser. : Ekonomika, pravo, politolohiia, turyzm. - K., 2011. Vyp. 1 (3). - S. 90-99.

12. Nazarov, V. V. Deiaki aspekty zabezpechennia bezpeky pidpryiemnytskoi diialnosti / V. V. Nazarov // Materialy Vseukr. naukovo-prakt. konf.: [«Nederzhavna systema bezpeky pidpryiemnytstva yak skladova natsionalnoi bezpeky Ukrainy»]. - K., 2013. - S. 60-61.

13. Sazonets, I. L. Mizhnarodni standarty bezpeky pidpryiemstv: navch. posib./ I. L. Sazonets. Rivne: Volyn. oberehy, 2015. - 352 s.

14. Nashynets-Naumova A. Iu. Pravove rehuliuvannia informatsiinoi bezpeky korporatsii / A. Iu. Nashynets-Naumova // Pravova informatyka. - 2014. - № 4 (44). - C. 95-99.

Надійшла до редколегії 15.02.2016 